\section{Noticias y comentarios}

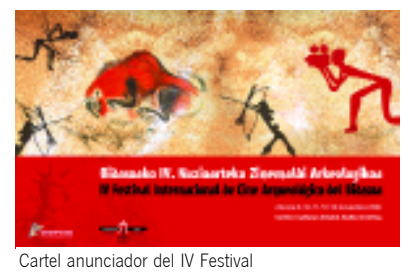

\title{
"Tras la huella de los Celtas" recibe el Gran Premio del Festival de Cine Arqueológico del Bidasoa
}

Entre los días 9 y 13 del pasado mes de noviembre, la ciudad de Irún (Guipúzcoa) ha servido una vez más de punto de encuentro para todas aquellas personas aficionadas a las películas documentales sobre arqueología. El Festival Internacional de Cine Arqueológico del Bidasoa, que nació en el año 2001 dentro del plan de difusión del Museo Oiasso, ha intentado desde su inicio reunir el cine y la arqueología como un instrumento novedoso y eficaz de transmisión de los conocimientos. La edición del año 2004 del Festival podría considerarse como la de su consolidación. La conversión de muestra de documentales en festival competitivo y la gran acogida dispensada por el público permiten hacer pensar que estamos ante una actividad cultural, patrocinada por el Ayuntamiento de Irún y organizada por el Centro de Estudios e Investigaciones Histórico Arqueológicas Arkeolan, que tendrá continuidad y seguirá afianzando su trayectoria en años venideros.

La edición de 2004 ha significado un punto de inflexión al existir por primera vez tres premios con los que reconocer la calidad de los trabajos presentados y su acierto en la transmisión de los contenidos científicos (ver cuadro adjunto). Esta nueva orientación del Festival no ha supuesto, sin embargo, el abandono de dos de sus rasgos más destacables: incluir dentro de la programación una película de ficción y otra orientada al público infantil. En la primera edición, además de proyectarse una versión de La momia, dirigida por Karl Feund en 1933, se pudo ofrecer como primicia el estreno en la ciudad de Irún de la película En construcción, dirigida por José Luis Guerín y que, tras su paso por el Festival Internacional de Cine de San Sebastián, aún no había sido estrenada en salas comerciales. En años sucesivos, se proyectaron Faraón (1966) y Gladiator (2000), mientras que, en la edición actual, el filme programado ha sido El rey Arturo (2004).

También se ha querido mantener, tras las proyecciones de los documentales, la posibilidad de establecer debates e intercambios de opiniones entre el pú- blico y los autores de las películas, así como arqueólogos y científicos que han colaborado en las mismas. Esta fórmula ha venido probando su atractivo a lo largo de las distintas ediciones, permitiendo la interacción con una audiencia no necesariamente erudita en temas de arqueología, pero con una curiosidad espoleada por la programación del Festival.

En la cuarta edición del Festival, el comité de selección recibió una veintena de películas, de las cuales fueron admitidas once que abordaban los más variados aspectos de la disciplina arqueológica, desde la descripción de procesos experimentales hasta la de grandes yacimientos, pasando incluso por un corto de animación que reproducía un episodio de la mitología griega.

\begin{tabular}{l}
\hline Premios del IV Festival de Cine \\
Arqueológico \\
Gran Premio del Festival \\
> Tras la Huella de los Celtas (Marc Jampolsky, 2003) \\
Menciones especiales \\
> Aquiles en la isla de Skyros (José Luis Gómez Me- \\
rino, 2003) \\
> Metalla Oiassonis. Las minas romanas de Oiasso \\
(Giorgio Studer, 2004) \\
Premio Especial del Público \\
> En busca del Faraón perdido (Pierre Stine, 2003) \\
Premio Arkeolan a la mejor divulgación científica \\
> Metalla Oiassonis. Las minas romanas de Oiasso \\
(Giorgio Studer, 2004) \\
Más información: \\
ARKEOLAN \\
Web: umw.arkeolan.com/cine4.htm \\
Correo-e.: arkeolan@arkeolan.com
\end{tabular}

Susana Prado Álvarez

Coordinadora del Festival

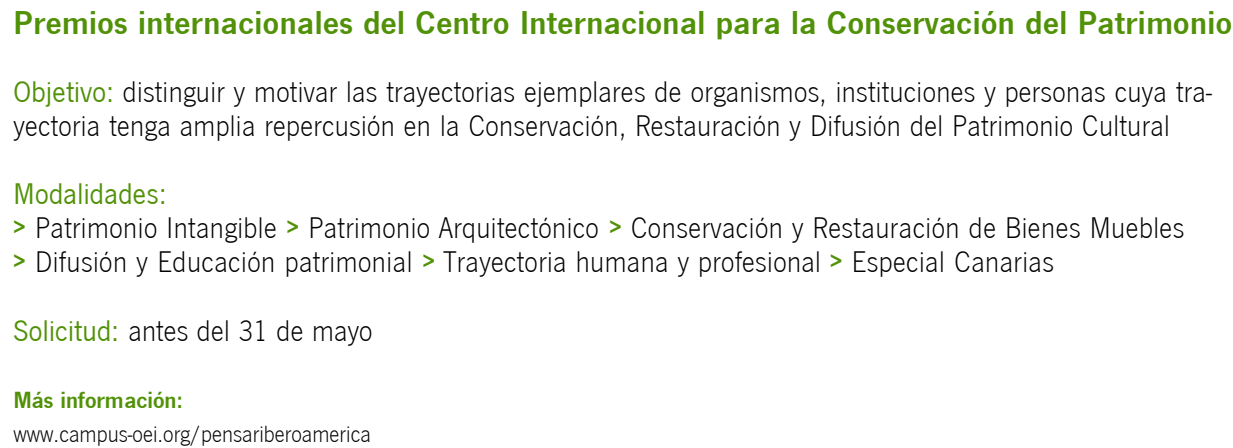

